\title{
ANALISIS Kemampuan SisWA dalam MENYELESAIKAN Soal High ORDER THINKING DITINJAU DARI KEMAMPUAN AWAL MATEMATIS SISWA
}

[Studi Penelitian Embedded Concurrent Pada Kelas X di SMAN 1 Garut]

\section{Analysis 0f Students Ability In Solving High ORder Thinking Problems BASED ON MATHEMATICAL INITIAL ABILITY STUDENTS}

[Embedded Concurrent Research Studies in Class X SMAN 1 Garut]

\author{
Zakkina Gaiss $^{1}$ dan Ekasatya Aldila Afriansyah ${ }^{2}$ \\ 1 Program Studi Pendidikan Matematika, STKIP Garut \\ Garut, Jawa Barat, Indonesia \\ zakkinagais@gmail.com \\ 2 Program Studi Pendidikan Matematika, STKIP Garut \\ Garut, Jawa Barat, Indonesia \\ e_satya@yahoo.com
}

\begin{abstract}
Abstrak
Penelitian ini bertujuan untuk mengetahui pengaruh kemampuan awal matematis siswa terhadap penyelesaian soal-soal high order thinking ditinjau dari soal analisis, soal evaluasi, soal mencipta dan secara umum. Penelitian ini pun bertujuan untuk mengetahui kemampuan siswa dalam menyelesaikan soal-soal high order thinking serta untuk mengetahui faktor-faktor yang menyebabkan siswa keliru dalam menyelesaikan soal-soal high order thinking. Metode penelitian yang digunakan adalah metode campuran dengan jenis embedded concurrent. Dari hasil penelitian diperoleh terdapat pengaruh kemampuan awal matematis siswa terhadap penyelesaian soal high order thinking dalam segala aspek. Siswa dikategorikan mampu menyelesaikan soal-soal high order thinking. Faktor-faktor yang menyebabkan siswa keliru dalam menyelesaikan soal-soal high order thinking diantaranya adalah kurang teliti dalam proses pengerjaan soal, kemampuan awal matematis siswa yang rendah, proses yang dilalui selama pembelajaran tidak maksimal, kurangnya pemahaman siswa terhadap soal, ketidaklengkapan dalam membaca soal dan kurangnya perhatian dari orang tua.

Kata Kunci: Analisis, Soal High Order Thinking, Kemampuan Awal.
\end{abstract}

\begin{abstract}
This research aims to know the effect of prior mathematical students ability to solve on high order thinking questions looked by analysis question, evaluation question, creating question and genera question. This research also aims to know about students ability in solving high order thinking question and to know about the factors that cause students to be wrong in solving high order thinking questions. The research method that used is mixed method with embedded concurrent type. From the result of the research, it is gotten there is an effect of prior mathematical students ability to solve high order thinking question in all aspects. Students are categorized able to solve high order thinking questions. The factors that cause student to be wrong in solving high order thinking question are less careful in the process of solving the question, the prior mathematical students ability is low, the process traversed during learning is not maximal, the lack students understanding to the question, incompleteness in reading the questions and the lack of attention of their parents.

Keywords: Analysis, High Order Thinking Question, Prior Ability
\end{abstract}

Jurnal "Mosharafa", Volume 6, Nomor 2, Mei 2017 


\section{Pendahuluan}

Terkait dengan isu perkembangan pendidikan di tingkat internasional, kurikulum 2013 dirancang dengan penyempurnaan. Model-model penilaian pada kurikulum 2013 mengadaptasi model-model penilaian standar internasional yang diharapkan dapat membantu peserta didik untuk meningkatkan kemampuan berpikir tingkat tinggi (High Order Thinking).

Namun pada kenyataannya hal tersebut belum terlaksana dengan baik. Pada pemantauan supervisi dan Pembinaan Pasca Evaluasi Hasil Belajar (EHB) SMA yang telah dilaksanakan oleh Direktorat Pembinaan SMA, sebagian besar guru SMA sasaran dalam menyusun butir soal cenderung hanya mengukur kemampuan berpikir tingkat rendah (Low Order Thinking). (Modul Penyusunan Soal High Order Thinking Skills, 2015: 1).

Berdasarkan pendapat Anderson \& Krathwohl (dalam Direktorat Pembinaan SMA, 2015: 4) "Domain proses kognitif yang termasuk dalam kemampuan berpikir tingkat tinggi (High Order Thinking) adalah domain analisis (analyze), evaluasi (evaluate) dan mencipta (create)".

Faktor kemampuan awal siswa dianggap paling berpengaruh, seperti diungkapkan Karso,dkk. (1993: 217) "Faktor siswa atau murid sebagai peserta didik merupakan faktor yang penting dalam proses belajar mengajar matematika. Ada faktor-faktor yang sepenuhnya tergantung pada siswa, seperti kecerdasan, kesiapan dan bakat anak".

Setiap individu mempunyai kemampuan yang berlainan. Menurut Yusuf (2011) "Kemampuan awal siswa adalah kemampuan yang telah dipunyai oleh siswa sebelum ia mengikuti pembelajaran yang akan diberikan. Kemampuan awal ini menggambarkan kesiapan siswa dalam menerima pelajaran yang akan disampaikan oleh guru".

Dalam penelitian ini peneliti memerlukan siswa-siswa yang memiliki kemampuan diatas rata-rata siswa pada umumnya. Peneliti memilih SMA Negeri 1 Garut sebagai tempat penelitian, karena menurut wikipedia (2016) "SMA Negeri 1 Garut merupakan SMA terbaik sekabupaten Garut terbukti dengan prestasi yang diraih dan akreditasi yang sangat baik". Berdasarkan hasil wawancara dengan salah satu guru SMA Negeri 1 Garut (2016), SMA Negeri 1 Garut menempati posisi ke 17 dalam Daftar SMA Terbaik Se-Indonesia. Selain itu didukung oleh passing grade SMA Negeri 1 Garut yang tinggi mengakibatkan siswa yang diterima oleh SMA Negeri 1 Garut adalah siswa-siswa terbaik.

Berdasarkan hasil observasi awal peneliti terhadap soal-soal yang sebelumnya diberikan oleh guru di SMA Negeri 1 Garut, hanya ada 10,9\% soal yang mengukur kemampuan analisis dan evaluasi, namun tidak terdapat soal yang mengukur kemampuan mencipta. Sedangkan dalam buku siswa matematika kelas $X$ yang digunakan sebagai sumber 
belajar siswa yang menerapkan kurikulum 2013 soal-soal yang mendominasi adalah soal-soal yang mengajak siswa untuk berpikir analisis, evaluasi dan mencipta.

Berdasarkan latar belakang yang telah diuraikan, maka rumusan masalah dalam penelitian ini adalah :

1. Bagaimana pengaruh kemampuan awal matematis siswa terhadap pengerjaan soal-soal high order thinking ditinjau:
a. Secara umum?
b. Dari aspek soal analisis?
c. Dari aspek soal evaluasi?
d. Dari aspek soal mencipta?

2. Bagaimana kemampuan siswa dalam menyelesaikan soal-soal high order thinking?

3. Faktor-faktor apa saja yang menyebabkan siswa keliru dalam menyelesaikan soal-soal high order thinking?

Ranah dalam Taxonomi Bloom Revisi digunakan untuk mengukur kemampuan berpikir tingkat tinggi. Anderson \& Krathwohl (dalam Direktorat Pembinaan SMA, 2015: 4) mengklasifikasikan dimensi proses kognitif sebagai berikut.

Tabel 1.

Klasifikasi Dimensi Proses Kognitif

\begin{tabular}{|c|c|c|}
\hline \multirow{3}{*}{ HOT } & Mencipta & $\begin{array}{l}\text { a) Mengkreasi ide/gagasan } \\
\text { sendiri. } \\
\text { b) Kata kerja : mengkonstruksi, } \\
\text { desain, kreasi, } \\
\text { mengembangkan, menulis, } \\
\text { memformulasikan. }\end{array}$ \\
\hline & & $\begin{array}{l}\text { a) Mengambil } \\
\text { sendiri. }\end{array}$ \\
\hline & Evaluasi & $\begin{array}{l}\text { b) Kata kerja : evaluasi, } \\
\text { menilai, menyanggah, } \\
\text { memutuskan, memilih, } \\
\text { mendukung. }\end{array}$ \\
\hline
\end{tabular}

\begin{tabular}{|c|c|c|}
\hline & $\begin{array}{l}\text { a) Menspesifikasi } \\
\text { aspek/elemen. }\end{array}$ & aspek- \\
\hline Analisis & $\begin{array}{l}\text { b) Kata kerja } \\
\text { membandingkan, } \\
\text { memeriksa, } \\
\text { mengkritisi. }\end{array}$ & menguji, \\
\hline
\end{tabular}

Menurut Yusuf (2011) "Kemampuan awal siswa adalah kemampuan yang telah dipunyai oleh siswa sebelum ia mengikuti pembelajaran yang akan diberikan. Kemampuan awal ini menggambarkan kesiapan siswa dalam menerima pelajaran yang akan disampaikan oleh guru". Atau dengan kata lain kemampuan awal adalah kemampuan prasyarat yang harus dimiliki siswa sebelum diberikan materi pembelajaran oleh guru.

Kemampuan awal dalam penelitian ini diambil dari hasil tes prasyarat yang telah diujicobakan sebelumnya dengan cakupan materi Eksponen, Logaritma, Persamaan dan Pertidaksamaan Nilai Mutlak dan Sistem Persamaan dan Pertidaksamaan Linear Tiga Variabel.

Peneliti berpendapat bahwa penelitian yang dilakukan mesti disesuaikan dengan kondisi sekolah, sehingga model yang digunakan adalah pembelajaran konvensional atau dengan kata lain model pembelajaran yang biasa dilakukan oleh guru yang bersangkutan. Berdasarkan pengamatan peneliti model pembelajaran yang guru matematika kelas X MIPA-3 biasa gunakan yaitu model discovery learning.

Langkah-langkah mengaplikasikan model discovery learning di kelas menurut Materi Pelatihan Guru Implementasi 
Kurikulum 2013 (2013: 215) adalah sebagai berikut:

1. Langkah persiapan discovery learning

a. Menentukan tujuan pembelajaran

b. Melakukan identifikasi karakteristik siswa (kemampuan awal)

c. Memilih materi pelajaran

d. Menentukan topik-topik yang harus dipelajari siswa

e. Mengembangkan bahan-bahan belajar

f. Mengatur topik-topik dari yang sederhana ke kompleks

g. Melakukan penilaian proses dan hasil belajar siswa

2. Prosedur aplikasi discovery learning

a. Stimulasi/ pemberian rangsangan

b. Pernyataan/identifikasi masalah

c. Pengumpulan data

d. Pengolahan data

e. Pembuktian

f. Menarik kesimpulan/generalisasi.

\section{Metode}

Penelitian ini menggunakan metode campuran terutama strategi embedded concurrent. Dalam penelitian ini data kuantitatif sebagai data primer dan didukung oleh data kualitatif sebagai data sekunder. Dalam penelitian ini, metode kuantitatif yang digunakan oleh peneliti adalah metode Quasi Eksperiment dengan sampel sebanyak satu kelompok. Yaitu kelompok yang diberikan model pembelajaran Discovery Learning sebagai kelas eksperimen. Sedangkan metode kualitatif yang digunakan adalah metode analisis deskriptif.
Adapun desain penelitian ini secara umum menggunakan desain penelitian campuran dengan jenis embedded concurrent menurut Creswell (2010: 315):

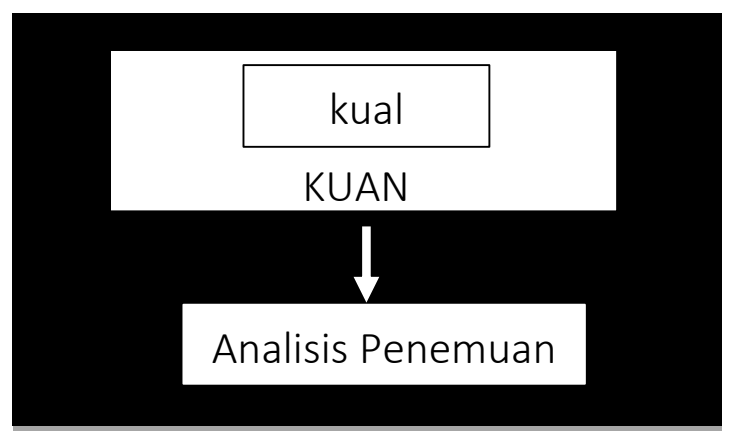

Gambar 1. Desain penelitian campuran dengan jenis embedded concurrent.

Desain penelitian menurut Arikunto (1989: 84):

\begin{tabular}{|cccc|}
\hline & Prasyarat & Perlakuan & Posttest \\
$\mathrm{E}$ & $\mathrm{O}_{1}$ & $\mathrm{X}$ & $\mathrm{O}_{2}$ \\
\hline
\end{tabular}

Keterangan:

$\mathrm{E}=$ kelas eksperimen

$\mathrm{O} 1$ = tes awal (prasyarat)

$\mathrm{O} 2$ = tes akhir (posttest)

$X=$ pembelajaran

Desain yang menunjukkan hubungan antara variabel menurut Sugiyono (2009:8):

$$
X \rightarrow Y
$$

$X \quad$ = kemampuan materi prasyarat

$\mathrm{Y}=$ kemampuan menyelesaikan soal

Populasi didefinisikan sebagai keseluruhan subjek atau objek yang menjadi sasaran penelitian yang mempunyai karakteristik tertentu (Sundayana, 2014: 15). Populasi dalam penelitian ini adalah seluruh siswa kelas $X$ SMA Negeri 1 Garut. 
Sampel adalah sejumlah (tidak semua) hal yang diobservasi atau diteliti yang relevan dengan masalah penelitian, dan tentunya subjek atau objek yang diteliti tersebut (Sundayana, 2014: 16). Sampel dalam penelitian ini diambil secara acak sebanyak satu kelas yaitu kelas X MIPA-3, dengan fokus penelitian 5 orang siswa.

Penelitian ini dilaksanakan pada semester genap tahun akademik 2016/2017 pada tanggal 9 sampai dengan 31 Januari 2017. Tempat pelaksanaan penelitian di SMA Negeri 1 Garut yang beralamat di Kecamatan Tarogong Kidul, Kabupaten Garut.

\section{A. Teknik Pengumpulan Data}

\section{Tes Soal High Order Thinking}

Instrumen yang digunakan dalam penelitian ini adalah berupa tes soal high order thinking. Adapun soal tes yang digunakan pada tes kemampuan awal terdiri dari 6 soal uraian dan tes akhir terdiri dari 6 soal uraian yang berbeda.

Tes kemampuan awal matematis merupakan tes yang dilakukan sebelum memperoleh perlakuan, hal ini bertujuan untuk mengetahui kemampuan awal siswa. Tes akhir diberikan kepada kelas eksperimen yang telah memperoleh perlakuan, yang dimaksudkan untuk mengetahui kemampuan siswa dalam menyelesaikan soal-soal high order thinking.

2. Angket

Angket ini dibuat berdasarkan pedoman wawancara, untuk melihat validitas dari instrumen pedoman wawancara yang dibuat. Angket ini diberikan setelah pelaksanaan tes akhir pada kelas eksperimen.

3. Wawancara

Wawancara mengacu kepada bagaimana cara berfikir siswa dalam menyelesaikan soal, serta faktor-faktor lain yang menunjang siswa dalam belajar dan mengerjakan soal. Wawancara dilakukan kepada 5 orang siswa, yaitu 1 siswa yang tergolong berkemampuan tinggi, 2 siswa yang tergolong berkemampuan sedang dan 2 siswa yang tergolong berkemampuan rendah.

\section{B. Teknik Analisis Data Kuantitatif}

Setelah data yang diperlukan terkumpul, maka dilakukan analisis data dengan memakai pendekatan statistik.

\section{Teknik Analisis Data Kualitatif}

Analisis ini bertujuan untuk mengetahui kemampuan siswa menyelesaikan soalsoal High Order Thinking dan mengetahui faktor-faktor yang menyebabkan siswa keliru dalam menyelesaikan soal-soal High Order Thinking maka peneliti menggunakan analisis jawaban siswa, observasi, angket dan wawancara.

\section{Hasil dan Pembahasan}

Dalam penelitian yang dilakukan dari 37 siswa yang menjadi subjek penelitian, 36 siswa yang memberikan datanya secara lengkap dan sesuai penelitian yang dibutuhkan. Diambil 6 siswa yang menjadi fokus penelitian, 2 siswa berkemampuan tinggi, 2 siswa berkemampuan sedang dan 
2 siswa berkemampuan rendah. Sebanyak

1 siswa yang berkemampuan tinggi tidak diikutsertakan data-datanya secara lengkap dalam penelitian ini, dikarenakan siswa tersebut tidak mengikuti Posttest, tidak mengisi lembar angket dan tidak mengikuti wawancara, hanya mengikuti tes prasyarat dan proses pembelajaran saja.

Tabel 2.

Hasil Data Tes Kemampuan Awal (Prasyarat) dan Posttest

\begin{tabular}{lcc|}
\hline Keterangan & Prasyarat & Posttest \\
\hline Jumlah siswa & 37 & 36 \\
\hline Skor Ideal & 60 & 72 \\
\hline Skor Terkecil & 23 & 28 \\
\hline Skor Terbesar & 54 & 69 \\
\hline Rata-rata & 36,78 & 54,31 \\
\hline Simpangan Baku & 6,70 & 9,75 \\
\hline $\begin{array}{l}\text { Jumlah Siswa } \\
\text { Berkemampuan Tinggi }\end{array}$ & 9 & 15 \\
\hline $\begin{array}{l}\text { Jumlah Siswa } \\
\text { Berkemampuan Sedang }\end{array}$ & 14 & 13 \\
\hline $\begin{array}{l}\text { Jumlah Siswa } \\
\text { Berkemampuan Rendah }\end{array}$ & 14 & 8 \\
\hline
\end{tabular}

Dari Tabel 2 diperoleh bahwa rata-rata posttest lebih besar dari pada prasyarat, juga nampak bahwa siswa yang berkemampuan tinggi bertambah.

Tabel 3.

Data Hasil Uji Normalitas

\begin{tabular}{rrrl}
\hline Tes & $L_{\text {maks }}$ & $L_{\text {tabel }}$ & Keterangan \\
\hline Prasyarat & 0,1099 & 0,1476 & $\begin{array}{l}\text { Berdistribusi } \\
\text { Normal }\end{array}$ \\
\hline Posttest & 0,1016 & 0,1497 & $\begin{array}{l}\text { Berdistribusi } \\
\text { Normal }\end{array}$ \\
\hline
\end{tabular}

Dari Tabel 3 diperoleh bahwa $L_{\text {maks }}$ tes prasyarat dan posttest berturut-turut adalah 0,1099 dan 0,1016. Sedangkan
$L_{\text {tabel }}$ tes prasyarat dan posttest adalah 0,1476 dan 0,1497. Dengan kriteria suatu data dikategorikan berdistribusi normal adalah $L_{\text {maks }}<L_{\text {tabel, }}$ maka dapat disimpulkan bahwa untuk data tes prasyarat dan posttest berdistribusi normal.

Analisis korelasi yang dilakukan adalah terhadap 4 aspek, yaitu secara umum, pada aspek analisis, aspek evaluasi dan aspek mencipta. Pada aspek analisis, aspek evaluasi dan aspek mencipta digunakan dua jenis data awal, data kemampuan awal secara keseluruhan dan data kemampuan awal hanya aspek yang digunakan saja.

Tabel 4.

Uji Pearson/ Product Moment

\begin{tabular}{|c|c|c|c|c|c|}
\hline \multicolumn{2}{|r|}{ Keterangan } & Nilai $r$ & $t_{\text {hitung }}$ & $t_{\text {tabel }}$ & Ho \\
\hline$r_{X Y}$ & $\begin{array}{l}\text { Secara } \\
\text { Umum }\end{array}$ & 0,56 & 3,95 & 2,03 & Ditolak \\
\hline$r_{X A}$ & Aspek & 0,54 & 3,81 & 2,03 & Ditolak \\
\hline$r_{\mathrm{A} 1 \mathrm{~A}}$ & $\begin{array}{c}\text { Soal } \\
\text { Analisis }\end{array}$ & 0,45 & 2,93 & 2,03 & Ditolak \\
\hline$r_{X E}$ & Aspek & 0,48 & 3,22 & 2,03 & Ditolak \\
\hline$r_{E 1 E}$ & $\begin{array}{c}\text { Soal } \\
\text { Evaluasi }\end{array}$ & 0,47 & 3,16 & 2,03 & Ditolak \\
\hline$r_{X M}$ & Aspek & 0,41 & 2,63 & 2,03 & Ditolak \\
\hline$r_{\mathrm{M} 1 \mathrm{M}}$ & $\begin{array}{c}\text { Soal } \\
\text { Mencipta }\end{array}$ & 0,35 & 2,18 & 2,03 & Ditolak \\
\hline
\end{tabular}

Dari tabel 4 setiap Ho ditolak, maka terdapat pengaruh kemampuan awal matematis siswa terhadap penyelesaian soal high order thinking secara umum, aspek soal analisis, aspek soal evaluasi dan aspek soal mencipta.

Untuk menjawab rumusan masalah mengenai bagaimana kemampuan siswa 
dalam menyelesaikan soal high order thinking, digunakan analsis jawaban siswa.

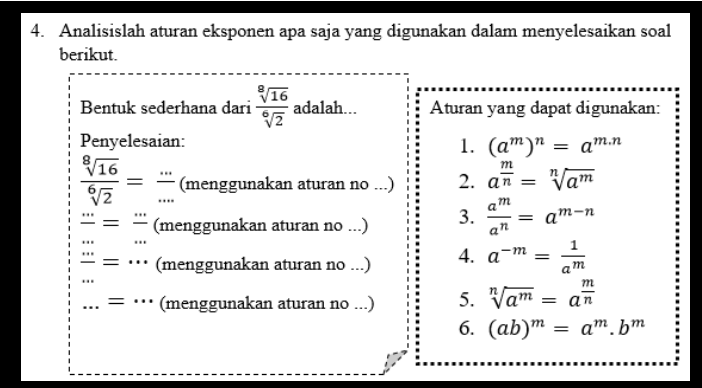

Gambar 2. Soal analisis prasyarat.

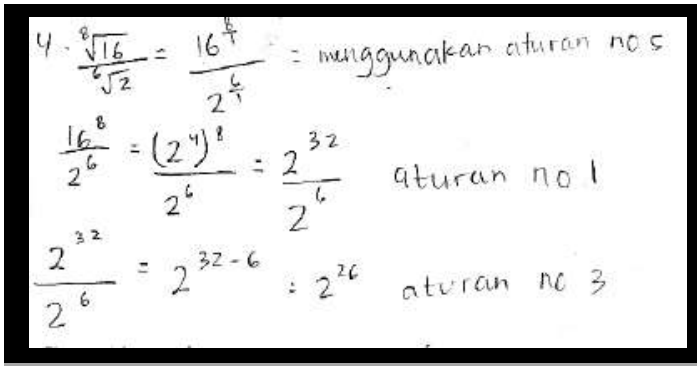

Gambar 3. Jawaban S-2.

Dalam menjawab soal analisis nomor 4 seperti tampak pada gambar 3, S-2 melakukan analisis dengan kurang tepat karena kesalahan konsep yang dipahaminya seperti 8 akar 16 dia rubah menjadi 16 pangkat 8 per 1 , kesalahan fatal yang mengakibatkan penyelesaian akhirnya kurang tepat, namun penggunaan aturan-aturan lainnya sudah ia pahami. Sedangkan S-1, S-3 dan S-4 melakukan analisis yang sesuai dengan tahapan penyelesaian yang terdapat dalam soal.

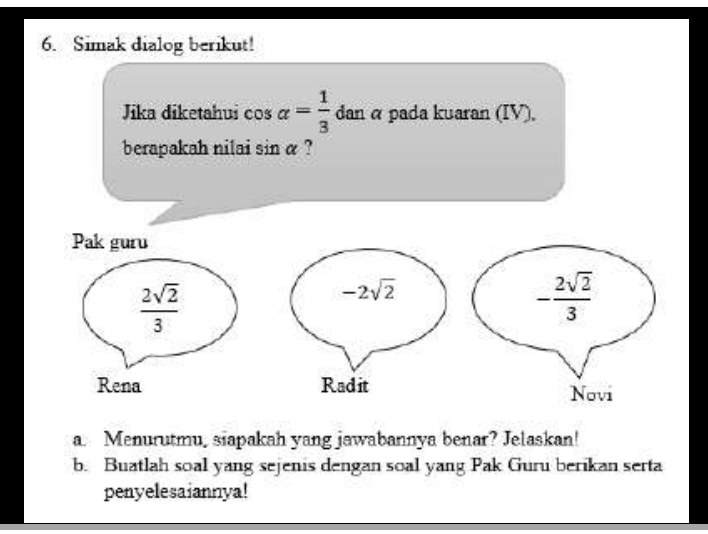

Gambar 4. Soal evaluasi dan mencipta posttest.

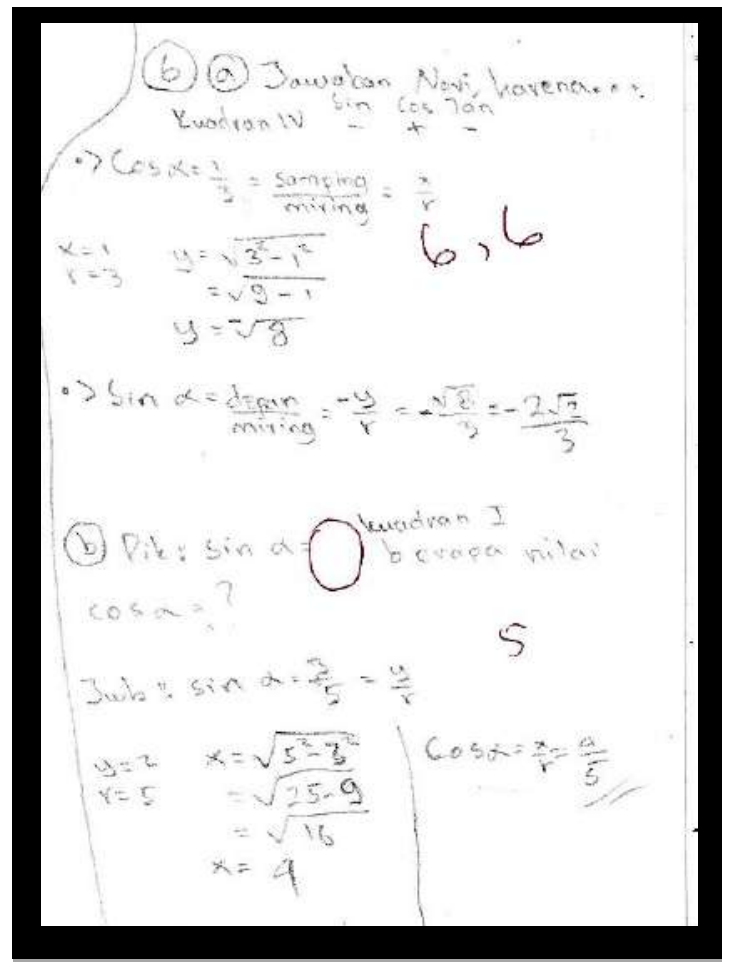

Gambar 5. Jawaban S-3.

Dalam menjawab soal evaluasi dan mencipta nomor 6 seperti tampak pada gambar 5, S-3 mengawali analisis dengan penempatan tanda pada kuadran IV juga menyelesaikan analisis dengan penyelesaian yang tepat sehingga menghasilkan evaluasi yang tepat, namun kurang sempurna dalam pembuatan soal karena tidak didicantumkan nilai, karena 
terlewat tak tertulis sehingga menjadi kurang sempurna.

Untuk memaparkan kemampuan dari enam siswa serta persentase penguasaan dari setiap aspek dihadirkan dalam bentuk tabel.

Tabel 5.

Rekapitulasi Perolehan Nilai Prasyarat dan Posttest

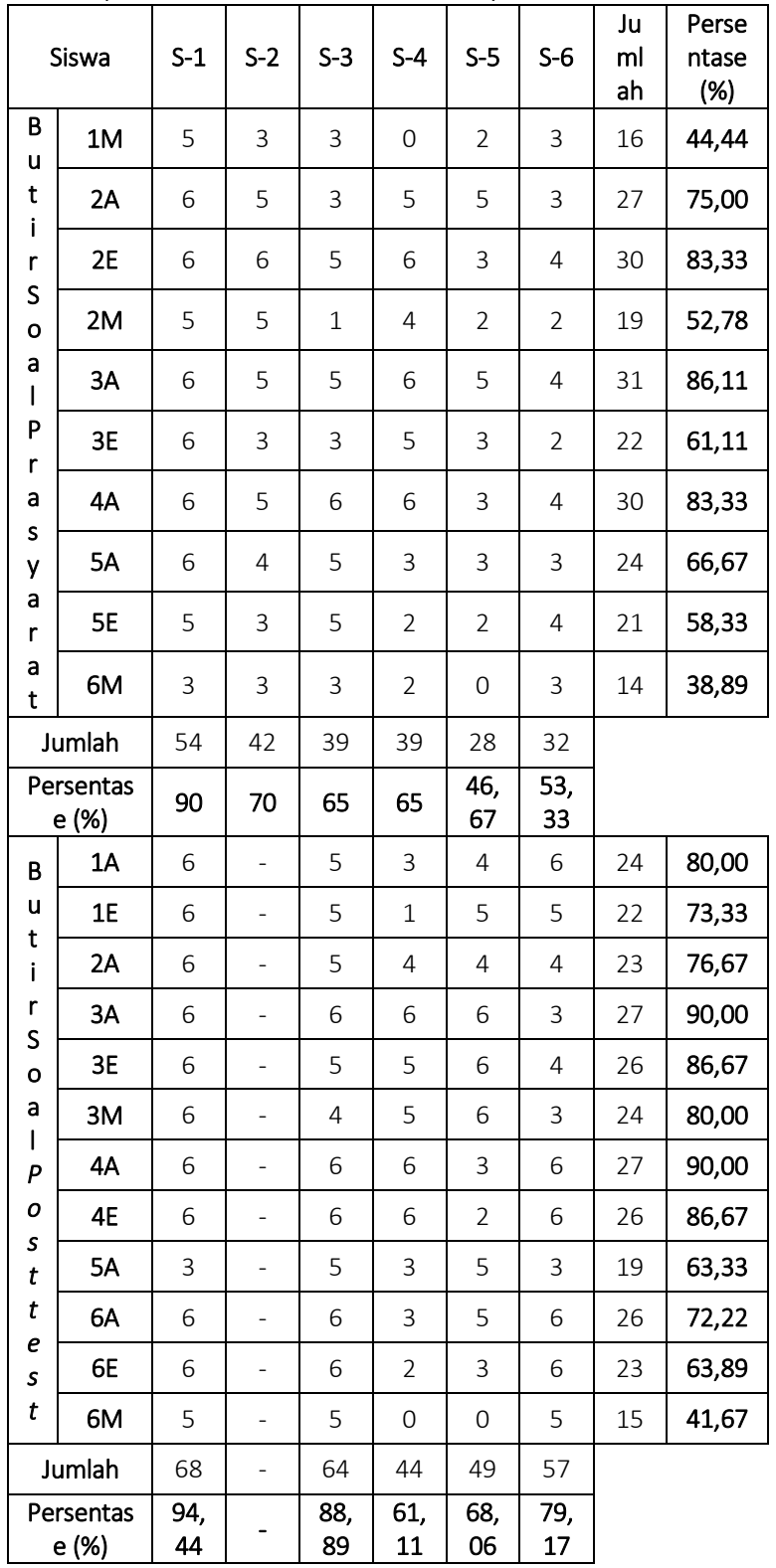

Dari tabel 5, kemampuan siswa dalam menyelesaikan soal-soal high order thinking berdasarkan aspek soal dapat dilihat dari rata-ratanya persentasenya. Untuk soal prasyarat atau kemampuan awal aspek analisis diperoleh 75,00\%, $86,11 \%$, 83,33\% dan 66,67\% sehingga rata-ratanya adalah $77,78 \%$ dan untuk aspek evaluasi diperoleh 83,33\%, 61,11\% dan 58,33\% sehingga rata-ratanya adalah $67,59 \%$ keduanya dikategorikan baik, sedangkan untuk aspek mencipta diperoleh $44,44 \%$, 52,78\% dan 38,89\% sehingga rata-ratanya adalah $45,37 \%$ dikategorikan cukup.

Sedangkan untuk soal posttest aspek analisis diperoleh 80,00\%, 76,67\%, $90,00 \%, 90,00 \%, 63,33 \%$ dan $72,22 \%$ sehingga rata-ratanya adalah $78,70 \%$ dan untuk aspek evaluasi diperoleh 73,33\%, $86,67 \%, 86,67 \%$ dan $63,89 \%$ sehingga rata-ratanya adalah $77,64 \%$ keduanya dikategorikan baik, sedangkan untuk aspek mencipta diperoleh $80,00 \%$ dan $41,67 \%$ sehingga rata-ratanya adalah 60,83\% dikategorikan cukup. Juga diperjelas pada tabel 6.

Tabel 6.

Persentase Kemampuan Siswa

\begin{tabular}{ccc|}
\hline \multicolumn{2}{c}{ Keterangan } & \multicolumn{1}{c}{$\begin{array}{c}\text { Persentase (\%) } \\
\text { Rata-rata }\end{array}$} \\
\hline \multirow{2}{*}{$\begin{array}{c}\text { Butir Soal } \\
\text { Prasyarat }\end{array}$} & Analisis & 77,78 \\
\cline { 2 - 3 } & Evaluasi & 53,33 \\
\cline { 2 - 3 } Mencipta & 45,37 \\
\hline \multirow{2}{*}{$\begin{array}{c}\text { Butir Soal } \\
\text { Posttest }\end{array}$} & Analisis & 78,70 \\
\cline { 2 - 3 } & Evaluasi & 77,64 \\
\cline { 2 - 3 } & Mencipta & 60,83 \\
\hline
\end{tabular}

Dari data hasil penelitian, pembahasan serta pengamatan terhadap lima siswa yang ikut serta dalam penelitian secara utuh peneliti berpendapat bahwa terdapat berbagai macam faktor yang 
menyebabkan siswa keliru dalam menyebabkannya adalah karena dalam menyelesaikan soal-soal high order thinking. Peneliti akan memaparkan berdasarkan kekeliruan serta faktor-faktor yang dialami tiap siswa.

Pertama, S-1 secara keseluruhan atau pada analisis, evaluasi dan mencipta tidak mengalami kekeliruan, S-1 hanya keliru pada penempatan tanda positif $(+)$ dan negatif (-) sehingga kekurang telitian S-1 mengakibatkan jawaban yang dipaparkannya menjadi kurang sempurna. Sehingga faktor kekeliruan dari S-1 adalah kurang teliti.

Untuk S-3 kekeliruan yang nampak adalah kurangnya kemampuan dalam mencipta pada kemampuan awal matematisnya, namun setelah melalui proses pembelajaran kemampuan S-3 dalam mencipta semakin meningkat. Kekeliruan lain yang dialami S-3 adalah keliru dalam penempatan rumus serta perhitungan yang kurang tepat sehingga kemampuan S-3 tetap pada kemampuan yang sedang karena melakukan beberapa kesalahan dalam analisis serta evaluasi. Sehingga faktor kekeliruan dari S-3 adalah kemampuan awalnya karena kemampuan awalnya berpengaruh terhadap penyelesaiannya dalam soal.

Untuk S-4 kekeliruan yang dialaminya adalah kesalahan dalam memahami soal yang diberikan serta ke tidak fokusan dalam pelaksanaan pengerjaan soal. Pada awalnya S-4 berkemampuan sedangkan pada posttest S-4 mengalami penurunan kemampuan dilihat dari penurunan nilai yang didapatnya. Faktor yang

proses pembelajaran S-4 tidak mengikuti secara serius atau banyak tidak fokus dalam proses diskusi kelompok serta banyak mengobrol dengan teman kelompok yang lainnya serta tidak banyak bertanya mengenai lembar kerja yang dikerjakan pada proses pembelajaran. Ketika S-4 ditanya apakah S-4 mengerti apa yang ada dalam lembar kerja S-4 menjawab paham, sedangkan pada penyelesaian soal S-4 banyak mengalami kekeliruan. S-4 menyatakan bahwa soal nomor 1 adalah mudah tapi tetap salah dalam mengerjakannya. Sehingga faktor kekeliruan yang dialami oleh S-4 adalah tidak fokus dalam mengerjakan soal serta tidak mengikuti pembelajaran dengan baik.

Untuk S-5 kekeliruan yang dialaminya adalah ketidak pahamannya terhadap soal yang diberikan, setelah menanyakan kepada guru, dan guru memberikan sedikit penjelasan barulah S-5 dapat mengerjakan soal yang tidak dipahami sebelumnya. Kemampuan awal S-5 rendah namun setelah mengikuti pembelajaran kemampuannya sedikit mengalami peningkatan, namun masih kesulitan dalam membuat soal sejenis. Meski S-5 pernah tidak mengikuti satu pertemuan namun tetap dapat menguasai materi yang tertinggal meski tidak sempurna. Sehingga faktor kekeliruan yang dialami S5 adalah kurang memahami terhadap soal sehingga sulit mengerjakan soal sehingga S-5 bukan mengerti dengan sendirinya. 
Untuk S-6 faktor yang menyebabkan kekeliruan dalam pengerjaan soal adalah kekurang lengkapan dalam membaca soal sehingga pengerjaan soalnya menjadi berantakan. Sebenarnya jawaban yang disampaikan S-6 telah mengarah pada jawaban akhir yang sesuai namun ada bagian-bagian yang tidak dituliskannya atau hanya ada di otaknya saja. Karena soal yang digunakan adalah soal analisis dan evaluasi sehingga mengharuskan jawaban menggunakan penjelasan namun S-6 kurang dalam menjelaskan analisis dan evaluasi yang dilakukannya sehingga mengakibatkan kemampuannya menjadi rendah. Serta faktor lainnya yaitu faktor perhatian dari orang tua terhadap nilai siswa yang kurang, hal tersebut cukup berpengaruh terhadap sikap pada pembelajaran dan juga hasil akhir pembelajaran. Sehingga faktor kekeliruan yang dialami S-6 adalah tidak membaca soal dengan lengkap dan kurang perhatian dari orang tua.

Faktor-faktor yang menyebabkan siswa keliru dalam menyelesaikan soal-soal high order thinking dapat terlihat dari hasil data pengerjaan soal siswa, observasi, angket dan wawancara. Dari hasil data pengerjaan soal diperoleh faktor kekeliruan berupa kurang telitinya siswa dalam proses pengerjaan soal. Dari hasil data observasi didapat faktor kekeliruan berupa kemampuan awal matematis siswa yang rendah dan proses yang dilalui selama pembelajaran tidak maksimal. Dan dari hasil data angket dan wawancara didapat faktor kekeliruan berupa kurangnya pemahaman siswa terhadap soal, ketidak lengkapan dalam membaca soal dan kurangnya perhatian dari orang tua. Faktor-faktor ini terrangkum dalam tabel 7.

Tabel 7.

Faktor-Faktor yang Menyebabkan Siswa Keliru

\begin{tabular}{|c|c|}
\hline Hasil Data & Faktor Kekeliruan \\
\hline $\begin{array}{l}\text { Pengerjaan } \\
\text { Soal }\end{array}$ & $\begin{array}{l}\text { Kurang teliti dalam proses } \\
\text { pengerjaan soal }\end{array}$ \\
\hline \multirow[t]{2}{*}{ Observasi } & $\begin{array}{l}\text { Kemampuan awal matematis siswa } \\
\text { yang rendah }\end{array}$ \\
\hline & $\begin{array}{l}\text { Proses yang dilalui selama } \\
\text { pembelajaran tidak maksimal }\end{array}$ \\
\hline \multirow{3}{*}{$\begin{array}{l}\text { Angket dan } \\
\text { Wawancara }\end{array}$} & $\begin{array}{l}\text { Kurangnya pemahaman siswa } \\
\text { terhadap soal }\end{array}$ \\
\hline & $\begin{array}{l}\text { Ketidaklengkapan dalam membaca } \\
\text { soal }\end{array}$ \\
\hline & Kurangnya perhatian dari orang tua \\
\hline
\end{tabular}

\section{Penutup}

Berdasarkan hasil penelitian dan pembahasan secara keseluruhan, sehingga dapat ditarik kesimpulan sebagai berikut:

1. Pengaruh kemampuan awal matematis siswa terhadap pengerjaan soal-soal high order thinking ditinjau:

a. Secara umum, terdapat pengaruh kemampuan awal siswa terhadap penyelesaian soal high order thinking secara umum.

b. Berdasarkan aspek analisis, terdapat pengaruh kemampuan awal siswa terhadap penyelesaian aspek soal menganalisis.

c. Berdasar aspek evaluasi, terdapat pengaruh kemampuan awal siswa terhadap penyelesaian aspek soal mengevaluasi.

d. Berdasarkan aspek mencipta, terdapat pengaruh kemampuan 
awal siswa terhadap penyelesaian

aspek soal mencipta.

2. Siswa dikategorikan mampu dalam menyelesaikan soal-soal high order thinking. Untuk soal prasyarat atau kemampuan awal aspek analisis adalah 77,78\% dan untuk aspek evaluasi adalah 67,59\% keduanya dikategorikan baik, sedangkan untuk aspek mencipta adalah 45,37\% dikategorikan cukup. Sendangkan untuk soal posttest aspek analisis rata-ratanya adalah 78,70\% dan untuk aspek evaluasi adalah 77,64\% keduanya dikategorikan baik, sedangkan untuk aspek mencipta adalah 60,83\% dikategorikan cukup.

3. Faktor-faktor yang menyebabkan siswa keliru dalam menyelesaikan soal-soal high order thinking dapat terlihat dari hasil data pengerjaan soal siswa, observasi, angket dan wawancara. Dari hasil data pengerjaan soal diperoleh faktor kekeliruan berupa kurang telitinya siswa dalam proses pengerjaan soal. Dari hasil data observasi didapat faktor kekeliruan berupa kemampuan awal matematis siswa yang rendah dan proses yang dilalui selama pembelajaran tidak maksimal. Dan dari hasil data angket dan wawancara didapat faktor kekeliruan berupa kurangnya pemahaman siswa terhadap soal, ketidak lengkapan dalam membaca soal dan kurangnya perhatian dari orang tua.
Berdasarkan temuan penelitian yang peneliti lakukan, peneliti memberikan saran-saran sebagai berikut:

1. Penggunaan soal-soal high order thinking dapat digunakan oleh guru baik dalam proses pembelajaran maupun sebagai alat evaluasi siswa yang diharapkan dapat meningkatkan kemampuan matematis siswa.

2. Untuk penelitian selanjutnya dapat meneliti tentang peningkatan kemampuan siswa dalam menyelesaikan soal-soal high order thinking, karena yang dilihat dalam penelitian ini hanya pengaruh kemampuan awal siswa terhadap penyelesaian soal-soal high order thinking.

3. Guna meningkatkan kemampuan high order thinking, seyogyanya siswa dibiasakan untuk memecahkan soalsoal high order thinking.

4. Sesuai dengan batasan masalah dalam penelitian ini terbatas pada model pembelajaran discovery learning dengan pokok bahasan trigonometri serta indikator yang digunakan adalah analisis, evaluasi dan mencipta. Sehubungan dengan keterbatasan tersebut, peneliti menyarankan kepada peneliti selanjutnya untuk meneliti dalam ruang lingkup yang lebih luas, dengan jenjang dan pokok bahasan yang berbeda. 


\section{DAFTAR PUSTAKa}

Arikunto, S. (2009). Prosedur Penelitian

Suatu Pendekatan Praktek. Jakarta. Rineka Cipta.E.A.

Creswell, J. W. (2010). RESEACH DESIGN:

Pendekatan Kualitatif, Kuantitatif dan

Mixed. Yogyakarta, Pustaka Pelajar.

Karso, dkk. (1993). Materi Pokok Dasardasar Pendidikan MIPA. Jakarta. Universitas Terbuka, Depdikbud.

NN. (2015). Modul Penyusunan Soal Higher Order Thingking Skill's Sekolah Menengah Atas, Direktorat Pembinaan Sekolah Menengah Atas Direktorat Jendral Pendidikan Menengah Kementrian Pendidikan dan Kebudayaan Tahun 2015.

Sugiyono, (2009). Statistika Untuk Penelitian. Bandung: ALPABETA R

Sundayana, R. (2014). Statistika Penelitian Pendidikan. Garut. STKIP Garut Press.
Wikipedia. (2016). SMA Negeri 1 Garut. https://id.wikipedia.org/wiki/SMA Ne geri 1 Garut [Online] [27 Mei 2016].

\section{Riwayat Hidup Penulis}

Zakkina Gais, S.Pd.

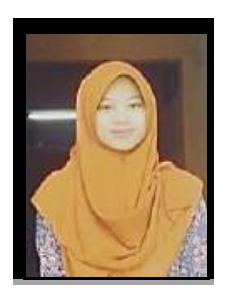

Lahir di Garut, 16 November 1994. Studi S1 Pendidikan Matematika STKIP Garut, lulus tahun 2017.

\section{Ekasatya Aldila Afriansyah, S.Si., M.Sc.}

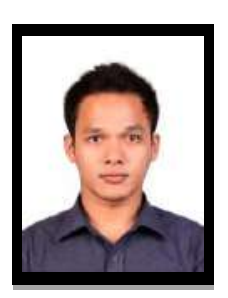

Lahir di Bandung, 4 April 1986. Dosen Tetap Yayasan STKIP Garut. Studi S1 Matematika Konsentrasi Statistika UPI, Bandung, lulus tahun 2009; S2 Pendidikan Matematika UNSRIUTRECHT, Palembang-Utrecht, lulus tahun 2012; dan S3 Pendidikan Matematika UPI, Bandung, sampai sekarang. 